\title{
Digital Photogrammetry - State of the Art and Potential for Application in Forest Management in Croatia
}

\begin{abstract}
Ivan Balenović and Forestry Economics Trnjanska cesta 35, 10000 Zagreb, Croatia ivanb@sumins.hr

\section{Dijana Vuletić}

Croatian Forest

Research Institute

Cvjetno naselje 41,

10450 Jastrebarsko

Croatia
\end{abstract}

Croatian Forest Research Institute Division for Forest Management

\author{
Ante Seletković \\ Faculty of Forestry, \\ University of Zagreb \\ Department of Forest \\ Inventory and Management \\ Svetošimunska 25, \\ 10000 Zagreb, Croatia \\ Elvis Paladinić \\ Croatian Forest \\ Research Institute; Division \\ for Forest Management \\ and Forestry Economics \\ Trnjanska cesta 35 , \\ 10000 Zagreb, Croatia
}

\author{
Renata Pernar \\ Faculty of Forestry, \\ University of Zagreb \\ Department of Forest \\ Inventory and Management \\ Svetošimunska 25, \\ 10000 Zagreb, Croatia \\ Jelena Kolić \\ Faculty of Forestry, \\ University of Zagreb \\ Department of Forest \\ Inventory and Management \\ Svetošimunska 25 , \\ 10000 Zagreb, Croatia
}

\author{
Hrvoje Marjanović \\ Croatian Forest Research Institute \\ Division for Forest Management \\ and Forestry Economics \\ Trnjanska cesta 35 , \\ 10000 Zagreb, Croatia

\section{Miroslav Benko} \\ Croatian Forest Research Institute \\ Division for Forest Management \\ and Forestry Economics \\ Trnjanska cesta 35 , \\ 10000 Zagreb, Croatia
}

\section{Abstract}

Background and purpose: The main goal of this paper is to inform forestry community about the latest developments in digital photogrammetry, as well as to present its possible application in forest management. For this purpose, the current state of technological development of the main tools of digital photogrammetry (digital aerophotogrammetric cameras and digital photogrammetric workstations) has been presented. Furthermore, two adjusted methods of manual digital photogrammetry for application in forest management, namely: method for strata delineation (i.e. creation of forest management division), and method for measuring stand structure elements have been developed and presented here.

Material and methods: Research was carried out on the selected part of multi-aged, privately owned forest of "Donja Kupčina - Pisarovina" management unit which includes 6 compartments and 24 subcompartments and covers total area of 480 ha. After conducted aerial survey of research area, acquired digital images were processed, and digital terrain model and digital elevation model were derived. Digital aerial images of ground sample distance of $10 \mathrm{~cm}$, topographical maps, digital terrain model and digital elevation model, as well as the digital photogrammetric workstations with appropriate software (PHOTOMOD, Global Mapper) were used for developing methods for strata delineation and stand structure elements estimation. Developments of both methods were carried out in the stereomodel of colour infrared digital aerial images in PHOTOMOD StereoDraw module. Additional data processing was conducted in

ArcGIS 9.1. (for strata delineation) and in Global Mapper (for stand structure elements estimation) software.

Discussion and conclusions: This research has showed that PHOTOMOD Lite and Global Mapper software packages in combination with the used materials (digital aerial images, digital elevation model) and digital photogrammetric workstation completely satisfy the needs for strata delineation and stand structure measurements. The PHOTOMOD software enables simple creation of projects of digital images, easy manipulation of multiple digital images, and many other features that facilitate photogrammetric measurement and photo-interpretation, but its free version PHOTOMOD Lite has limited capabilities in terms of number of images and quantity of vector data that can be processed. If digital images of high spatial resolution are used (e.g. $30 \mathrm{~cm}$ or better), as was the case in this research, stereo-effect experienced by the operator and the quality of photo-interpretation are very good. That enables clear determination of vegetation types and as well as single tree species, more accurate pinpointing of tree tops and more accurate delineation of tree crowns. As long as automatic procedures are not available, digital photogrammetry has to rely on manual methods. Allometric relation between variables measured with photogrammetric method and desired variables need to be developed. An attempt to address this issue, at least in part, is made within the ongoing project 'Application of digital photogrammetry in practical forest management'.

Keywords: digital photogrammetric workstation, digital aerial images, strata delineation, stand structure elements 


\section{INTRODUCTION}

In order to achieve faster, simpler and cheaper ways of collecting spatial data, remote sensing methods have been increasingly used in many disciplines, including forestry $[1,2]$.

Like in Europe and worldwide, a significant amount of research on possibilities of applying the remote sensing methods were also conducted in Croatia, especially photogrammetry in forestry practice, pioneered in the 1950s by professor Tomašegović [3-7]. From that time until today many research results were published, e.g. on application of aerial photographs in forest mapping and stand delineation [8-13], estimation of stand structure elements [10,14-23] as well as possibilities for forest damage assessment using colour infrared aerial photographs [24-30]. Most of these studies were carried out with photogrammetric measurement and photointerpretation of the classical analogue aerial photographs with analogue stereo instruments. Only recently a smaller number of studies were carried out using digital image analysis $[22,23]$.

Despite all conducted studies, photogrammetry has not reached a significant level of practical application in Croatian forestry yet. Among the numerous reasons, the main were: high costs of aerial photographs and of equipment, demanding office work that requires classical photogrammetric methods, lack of photogrammetric trained staff, distrust in new methods, technologies and obtained results which haven't often satisfied all the needs of forestry practice [31, 32].

In the meantime, during 1980s and 1990s, the development of computer technology had also had a big influence on the evolution of remote sensing methods. Thus, in the last thirty years photogramme-

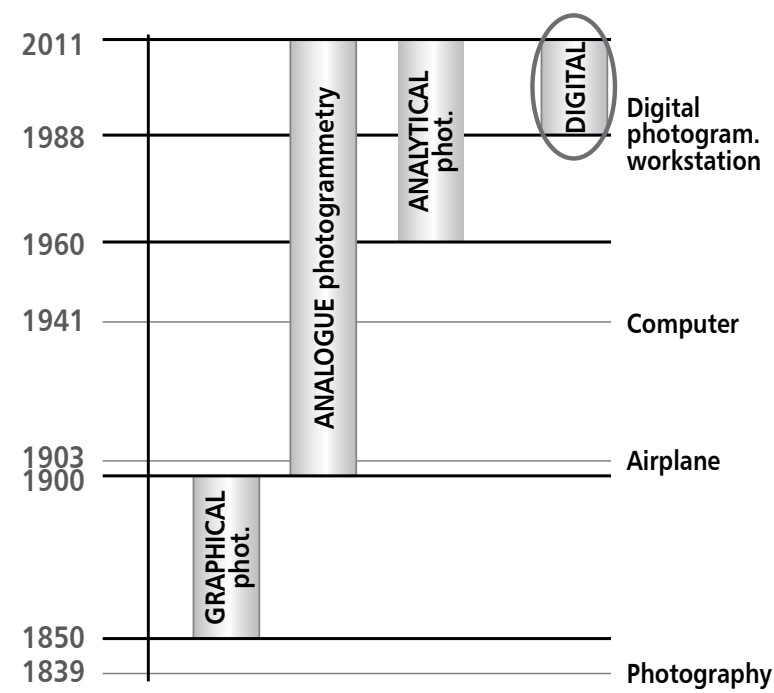

FIGURE 1

Phases of photogrammetric development, as a result of technological innovations (source [36]) try has developed from analogue, over analytical to digital photogrammetry [33] (Figure 1). During this development period, analogue aerial photographs as well as analogue or analytical stereo instruments were replaced by digital aerial images and by digital photogrammetric workstations [34, 35].

By the development of digital photogrammetry, primarily as a result of improvement in digital aerophotogrammetric cameras (DACs) that can capture digital images of high spatial, radiometric and spectral resolution, as well as by digital photogrammetric workstations (DPWs), the question of possible application of photogrammetry in practical forestry was reopened [32].

Therefore, the main goal of this paper is to inform forestry community about the latest developments in digital photogrammetry, as well as to present its possible application in forest management. For this purpose, the current state of technological development of the main tools of digital photogrammetry (DACs and DPWs) has been presented. Furthermore, methodology for application of digital aerial images and digital photogrammetric workstation in forest management have been developed and presented here.

\section{DIGITAL PHOTOGRAMMETRY}

Digital (softcopy) photogrammetry can be defined as the newest development phase of photogrammetry which includes the use of digital images captured by DACs or scanned analogue images as well as the use of DPWs in order to perform photogrammetric processing and to obtain photogrammetric products.

Simplified schematic workflow (Figure 2) shows DACs and DPWs as the main tools in digital photogrammetry.

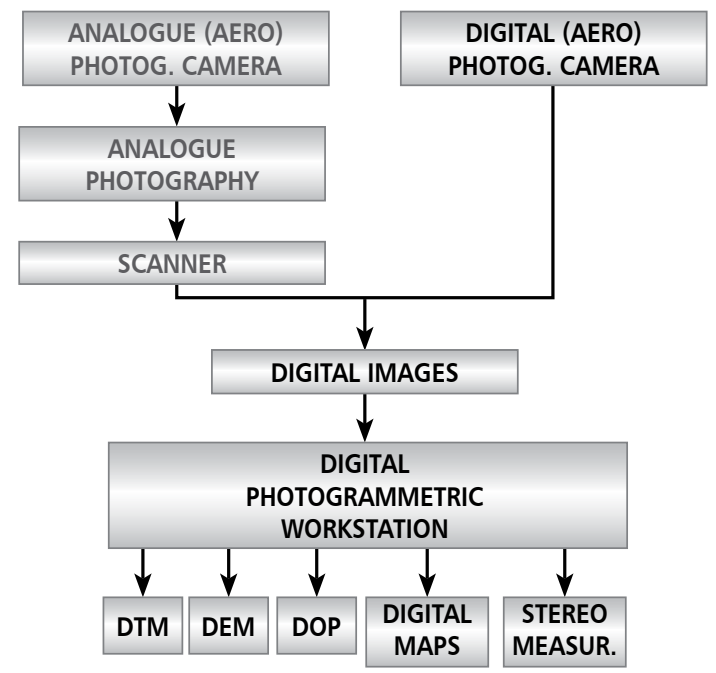

FIGURE 2

The simplified schematic workflow in digital photogrammetry 


\section{Digital aerophotogrammetric cameras (DACs)}

Although the term digital photogrammetry has been in use for a long time, namely when scanners were used to obtain digital image from analogue photographs, only with the appearance of digital cameras we can talk of fully digital photogrammetry. The first commercial solutions of DACs (ADS40 and DMC) were presented at the ISPRS (International Society for Photogrammetry and Remote Sensing) congress in 2000 in Amsterdam [37-39].

The appearance of DACs which, by its characteristics, could replace the existing analogue technology meant a big change for photogrammetry. During a single aerial survey, the majority of digital cameras simultaneously record panchromatic, red, blue, green and infrared part of electromagnetic spectrum. With the help of GPS (Global Positioning System) and IMU (Inertial Measurement Unit), it is possible to get oriented images right after airplane landing. Then the images are directly loaded into DPWs for further processing. The additional benefits of using DACs are that there are no longer needs for films, photolab developing and scanning. In this way, a whole phase of photogrammetric work process disappeared, resulting in time and costs savings [37, 38, 40-43].

An additional advantage, compared to the traditional film workflow, is the absence of noise introduced during the scanning process as a result of film grain, dust particles, scanner glass imperfections, etc. Furthermore, digital images have improved radiometric properties of the image which enables much more information to be extracted, especially from shadowed areas of the image. Digital images also outperformed the analogue ones in terms of spatial resolution. This led to the improved stereoscopic view and better possibility for interpretation from stereomodel derived from digital images. Electronic forward motion compensation device enables recording of high spatial resolution images at great flying speed, so the time interval between two recordings can be shorter than one second. Due to the properties of DACs, aerial recordings can be made under relatively low light conditions. This increased the length of the season suitable for recording, as well as extended daily time appropriate for aerial photo flight sessions [37, 40, 42-45].

A digital camera, in its main parts, is almost identical to the analogue one. The basic difference is in the media for light registration and the process of creating images. In analogue cameras the media is a film and the image is created photographically, i.e. by chemical reaction of light and film. In digital cameras, the film is replaced by an electronic photosensitive sensor which could be CCD (Charge Coupled Device) or CMOS (Complementary Metal Oxide Semiconductor) $[38,41,43]$.
According to the sensor size, i.e. the size of the resulting images, Petrie and Walker [43] differentiate digital cameras to:

- small format - up to 16 megapixels,

- medium format - from 16 up to 50 megapixels,

- large format - more than 50 megapixels.

Despite the increased appearance of small and medium format DACs, large format DACs still have the largest application and role in aerophotogrammetric surveys.

Finally, it is necessary to mention that the development of digital cameras is very dynamic and further technological advances can be expected.

\section{Digital photogrammetric workstations (DPWs)}

The first digital photogrammetric workstation Kern DSP1 was presented at the XVI ISPRS congress held in Kyoto in 1988. The DPW was defined as "a hardware and software connection to derive photogrammetric products from digital imagery". The advances in computer technology in the 1990s had great influence on the DPWs evolution and their expansion at the market. At the end of the same decade many photogrammetric companies and research institutions were using DPWs which gradually took domination over the analytical plotters $[46,47]$.

There are two main differences between DPWs and analytical plotters. The first and probably the most important is the input data (image type) which they use. DPWs use digital images, while analytical stereoinstruments use slides of analogue photographs. Besides aerial images, some of modern DPWs can process satellite or LiDAR images. The second important difference is the possibility of DPWs for partial or total automatization of photogrammetric processing [47, 48].

As any other ordinary computer, the DPW also consists of hardware and software. The main characteristic of DPW is a powerful hardware which implies powerful and fast processor (CPU), large memory (RAM) and large storage units. A part of the hardware which makes DPW significantly different from normal computer is the stereo viewing system consisted of graphic card, high resolution stereo monitor as well as a monitor suitable stereo glasses. Today the most widely used stereo viewing system is the one comprised of monitor with active polarization display and stereo glasses with polarization filters $[36,46,47,49$, 50].

The most important part of DPW is its software. Generally, photogrammetric tasks which can be performed using DPW are the following: basic photogrammetric functions (image orientation, aerial triangulation, image block adjustment), mono or stereo 
vectorization, more or less automated creation of digital terrain model (DTM) and digital elevation model (DEM), digital orthophoto, digital map, etc. [51-53].

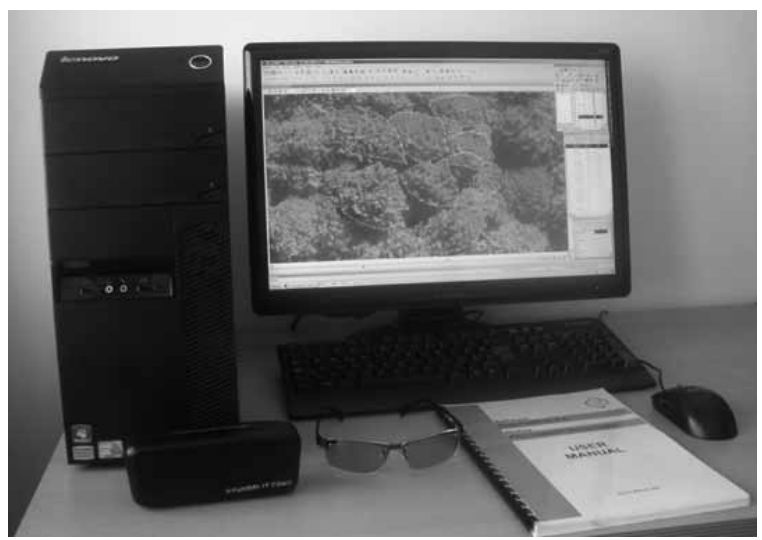

FIGURE 3

The digital photogrammetric workstation PHOTOMOD

\section{Short overview of past application of digital photogrammetry in forestry}

The initial development of digital photogrammetry in the 1990s had also encouraged foresters to start research on the possibility of its application in forestry. Based on a review of past research in application of digital photogrammetry in forest management, Benko and Balenović [54] differ:

- manual methods of photogrammetric measurement and visual interpretation (photo-interpretation) of digital aerial images using DPW [34],

- automated methods of photogrammetric measurement and interpretation of digital aerial images using a computer or DPW [55-63].

We found considerably more publications describing studies that make use of automated methods than those using manual methods (as can be seen from the above example). Manual methods are more labour intensive, i.e. they require much greater effort and knowledge of the interpreters, while in automated methods most of the work is performed by the computer. Thereby, time saving is achieved with automated methods. Also, by using automated methods, the influence of interpreter's subjectivity is eliminated [64]. However, despite these advantages, automated methods cannot reach manual methods in terms of accuracy yet, e.g. in determining tree species and in the estimation of stand structure elements in mixed stands. Therefore, the practical application of the automated methods is still problematic. Taking into consideration all things mentioned above, as well as constant technological advancement of DPWs and photogrammetric software, new research of the application of both automatic and manual methods of digital photogrammetry in practical forest management is necessary [54].
In the following section we will present two adjusted methods of manual digital photogrammetry for application in forest management in Croatia, namely: method for strata delineation (i.e. creation of forest management division), and method for measuring stand structure elements.

\section{MATERIALS AND METHODS}

Method for strata delineation and method for measuring stand structure elements, described here include the use of digital aerial images, digital terrain model (DTM) and digital elevation model (DEM), as well as the use of DPW with appropriate software. Typical software used with DPW includes software for photogrammetric processing of remote sensing data and geographic information system (GIS).

\section{Research area}

Research was carried out on the selected part of multi-aged, privately owned forest of "Donja Kupčina - Pisarovina" management unit (M.U.). Selected part includes 6 compartments and 24 subcompartments and covers total area of 480 ha (Figure 4). The dominant tree species: Sessile oak (Quercus petraea L.), Common beech (Fagus sylvatica L.), Hornbeam (Carpinus betulus L.), Black alder (Alnus glutinosa (L.) Gaertn.) and poplars (Populus sp.) form 4 main management classes (Sessile oak, Common beech, Hornbeam and Poplars) of the M.U.

\section{Aerial survey and derivation of DTM and DEM}

The colour infrared digital images were surveyed in July 2009 at a flight attitude of $1400 \mathrm{~m}$ above ground level and with approximate scale of $1: 1000$ by Vexcel UltracamX digital camera (Vexcel Imaging $\mathrm{GmbH}$, Graz, Austria). Focal distance of camera lenses was $100.5 \mathrm{~mm}$, while radiometric resolution was 12 bit. Forward overlap (endlap) of images was $60 \%$, while lateral (sidelap) was 30\%. In total, 23 images were acquired along two flight lines. Spatial resolution, i.e. ground sample distance (GSD) of acquired images was $10 \mathrm{~cm}$.

After the aerial survey, digital aerial images were processed by the Office Processing Center (OPC) software package that comes with the camera. Raw data (RAW files) of digital images were transformed into raster files in TIFF format with JPEG compression (quality level of $100 \%$ ) representing the final output data. The average size of images was about $197 \mathrm{MB}$. Aerial surveys of research area, as well as DTM and DEM derivation were performed by Geofoto Ltd, Zagreb.

Data for derivation of DTM (Figure $5 a$ ) of research area were collected by photogrammetric mapping of stereopars of digital aerial images on DPW Imagestation using Feature Collection, Automatic Elevation and DTM Collection modules (version 6.0). DTM data 


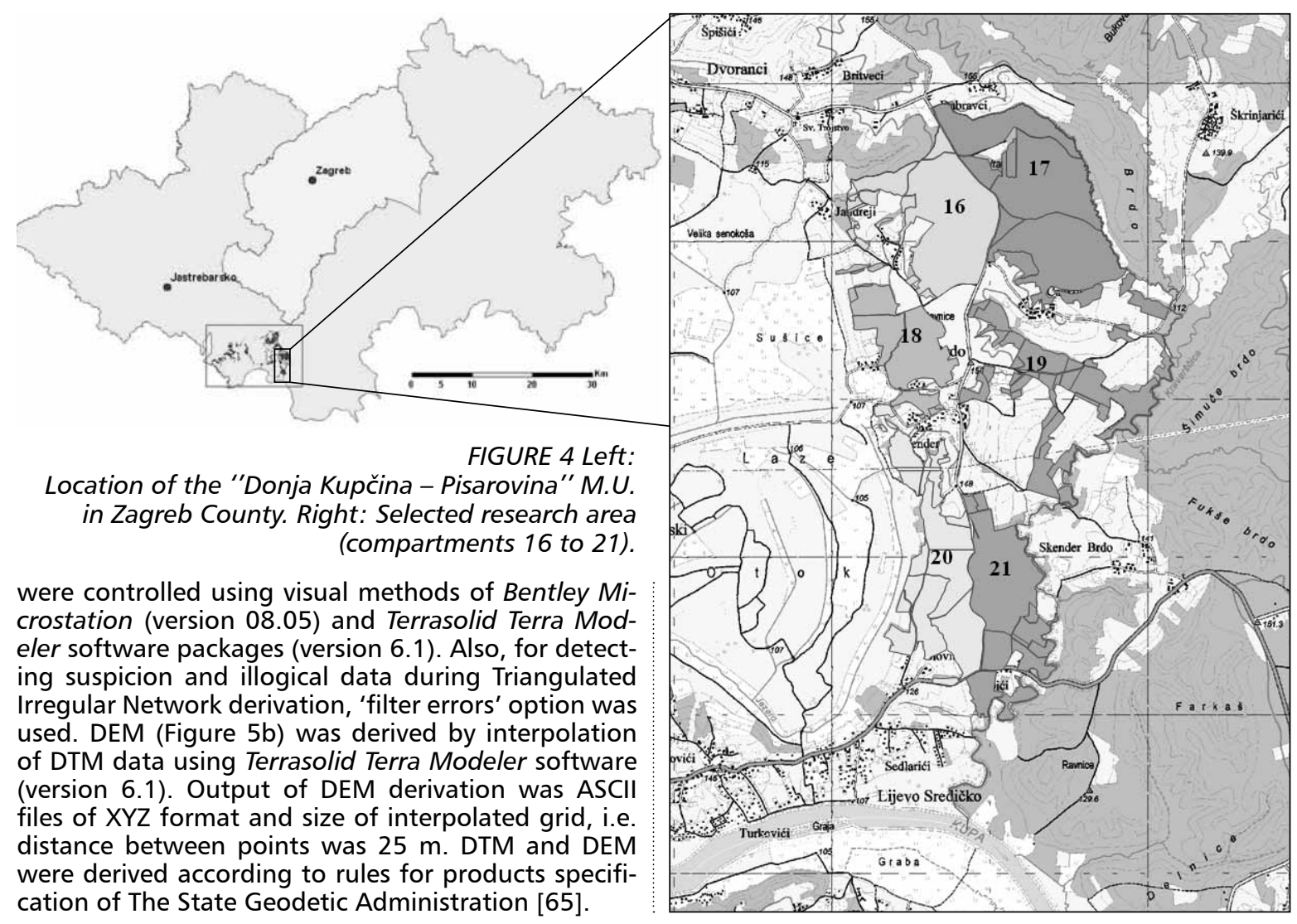

FIGURE 5a

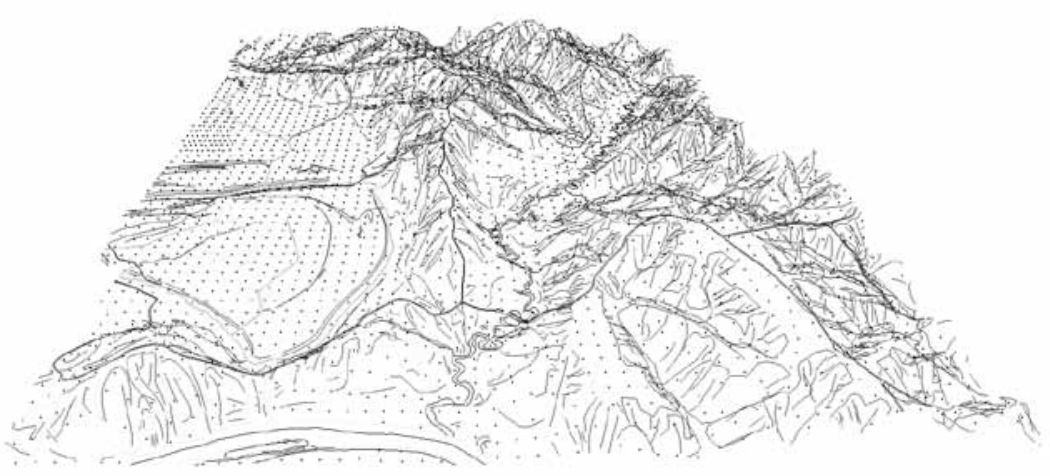

Digital terrain model (DTM).

FIGURE $5 b$

Digital elevation model (DEM) of research area. Both DTM and DEM are shown in $3 D$ view of Global Mapper.

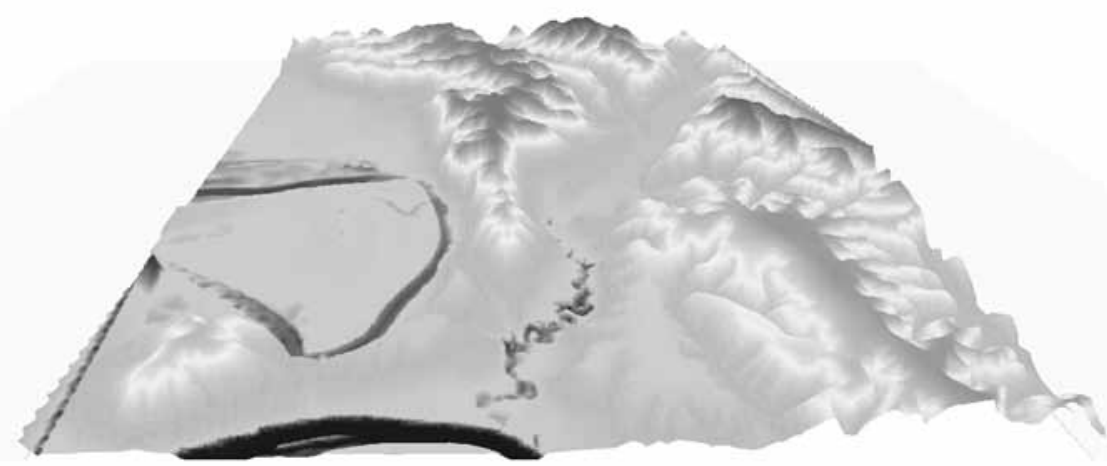




\section{PHOTOMOD and Global Mapper software}

There are many software for photogrammetric processing, as well as GIS software present at the market. We used free version of photogrammetric software PHOTOMOD Lite 4.4 [66]. Also, we used GIS software Global Mapper v11.01 [67], which came preinstalled with our DPW (Figure 3), as well as ArcGIS 9.1 software. However, other similar GIS software could also have been used instead.

In order to execute small photogrammetric projects PHOTOMOD Lite, a free version of PHOTOMOD digital photogrammetric system package, is appropriate. The Lite version has all features as full version of PHOTOMOD, but it can handle only limited number of images, vector objects, TIN nodes, break lines etc. For example, within one created project, the Lite version supports up to 10 digital aerial images in the central projection and extraction of vector objects up to 1000 points, allowing the performance of various photogrammetric tasks (vector objects collection, orthomosaics, DTMs and vector maps creation) [66]. However, in our case this was sufficient.

For application of the methods presented below two modules of PHOTOMOD Lite software were used:

- $\quad$ PHOTOMOD Montage Desktop - the core module of the digital photogrammetric system used to create and manage projects and operate different PHOTOMOD modules for further photogrammetric processing [68],

- $\quad$ PHOTOMOD StereoDraw - module for 3D feature extraction, i.e. creating, editing and measuring 3D vector objects in stereomode [69].

Before photo-interpretation and photogrammetric measurement, i.e. strata delineation and stand structure elements measurement on DPW, certain preparatory work was necessary.

In order to perform photogrammetric processing in PHOTOMOD it was necessary to first create the project. First step of the project creation is block forming when digital images are added to the project, followed by positioning (rotation) of images and the whole block. Then follows aerial triangulation of the project, which includes defining camera parameters, and the interior orientation of the aerial images. The exterior image orientation is carried out during the third step - block adjustment. Block processing is the last step in project formation when one of modules (StereoDraw, StereoVector, DTM) for further processing can be chosen [68]. Before creating or editing vector objects in the StereoDraw module, it is necessary to create the code table in which each object is defined and described by a code name, code number, shape (point, polyline, polygone), colour, symbol and additional attributes.

\section{Method of strata delineation}

Delineation of strata in forest, unless performed automatically by a computer, is in general subjective and depends on the experience of the person doing delineation. Typically, in forest delineation in the field a forester walks through the chosen part of forest and marks on the map distinctive points and lines where parts of forest stands differ. In manual delineation using photogrammetric method the procedure is similar. The photo-interpreter marks differences on the image between different parts of the forest. In both cases delineation has to be performed by a trained person, preferably familiar with forest on which she/ he is working. In most cases, as is in our case, in delineation by photo-interpretation it is necessary to acquire a photo-interpretation key. Therefore several field surveys with temporary field plots were performed with the aim to train the photo-interpreter. It is difficult to set a strict written set of rules for photointerpretation, particularly in diverse forests such as ours, so since photo-interpretation was performed by only one person we decided not to make a written photo-interpretation key. We used the approach where photo interpreter was first "trained" at the smaller part of the forest area, in order to perform photo-interpretation tasks on the remaining area.

Development of method of strata delineation for creating forest management division was carried out on the selected part of "Donja Kupčina - Pisarovina" M.U. using photo-interpretation in the stereomodel of colour infrared (CIR) digital aerial images in StereoDraw module.

Before the delineation it is necessary to define classification categories. In Croatia different categories and subcategories of forests and forest land are defined by Regulations for Forest Management [70, 71]. In our case, through preliminary review of existing digital aerial images of the research area and photo-interpretation training with field surveys we identified four main categories divided into total of 19 subcategories (Table 1 ).

Strata are delineated on the basis of observable differences on digital images, according to predefined categories: crown size and tree height (cover), tree species mixture, canopy closure and tree species (Figure 6).

After delineation, vectorized polygon objects were loaded in ArcGIS 9.1 software for further processing (adjustment with cadastral data). Topographical maps and digital orthophoto were used as background layer in GIS software for easier orientation.

If strata delineation is performed for privately owned forests, then 'overlapping' of delineated strata with cadastral register data of private forests must be done, in particular overlapping and adjustment with polygons of cadastral particles which are in cadastre 


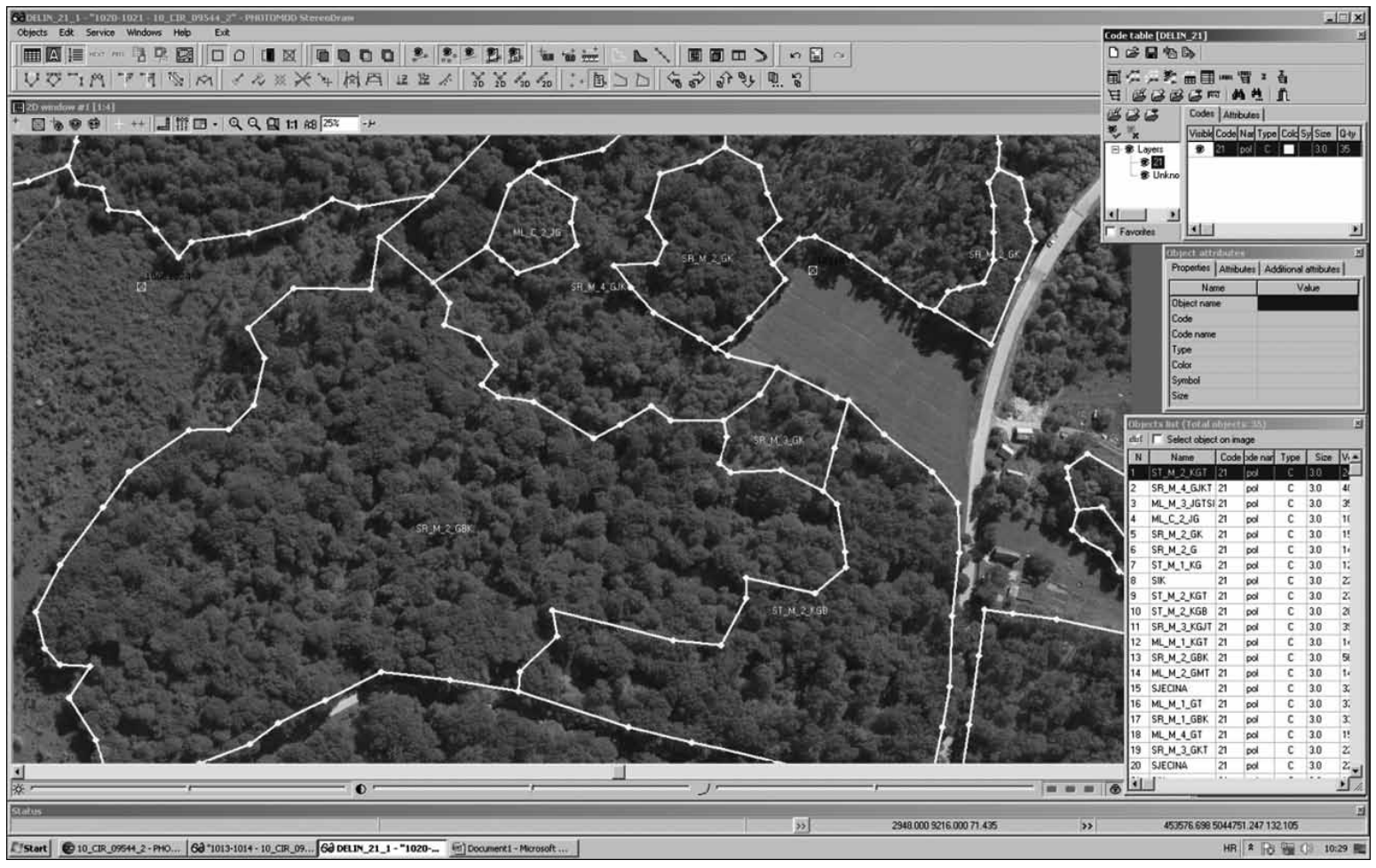

\section{TABLE 1}

Categories for forest and forest land classification for photo-interpretation of digital aerial images

\begin{tabular}{|c|c|c|}
\hline Category & Subcategory & $\begin{array}{c}\text { Sub- } \\
\text { category } \\
\text { code }\end{array}$ \\
\hline \multirow{7}{*}{ Cover } & High forest - Young & HF-Y \\
\hline & High forest - Middle-Aged & HF-MA \\
\hline & High forest - Old & $\mathrm{HF}-\mathrm{O}$ \\
\hline & Harvested Area & $\mathrm{HA}$ \\
\hline & Degraded (shrub) & DEG \\
\hline & Land In Succession & SUC \\
\hline & Land Without Vegetation & WV \\
\hline \multirow{3}{*}{ Mixture } & Pure & $\mathrm{P}$ \\
\hline & Mixed & $\mathrm{M}$ \\
\hline & Not applicable & NA \\
\hline \multirow{5}{*}{$\begin{array}{l}\text { Canopy } \\
\text { closure }\end{array}$} & Complete $(91-100 \%)$ & 1 \\
\hline & Incomplete (76-90\%) & 2 \\
\hline & Rare (50-75\%) & 3 \\
\hline & Broken $(<50 \%)$ & 4 \\
\hline & Not applicable & NA \\
\hline \multirow{7}{*}{$\begin{array}{c}\text { Main tree } \\
\text { species }\end{array}$} & Quercus petraea & QP \\
\hline & Fagus sylvatica & FS \\
\hline & Carpinus betulus & $\mathrm{CB}$ \\
\hline & Alnus glutinosa & AG \\
\hline & Populus sp. & POP \\
\hline & Other & OTH \\
\hline & Not applicable & NA \\
\hline
\end{tabular}

FIGURE 6

An example of strata delineated on digital aerial images of GSD $10 \mathrm{~cm}$ shown in $2 D$ window of StereoDraw module at mitigation of $25 \%$

registered as privately owned. In our case, delineated strata were corrected (adjusted) with cadastral data in order to delete strata or its parts which in cadastral is not registered as privately owned forests.

Finally, grouping of strata into management classes and then into subcompartments is conducted according to: (I) categories (Table 1) which are assigned to each strata during delineation (cover, mixture, canopy closure, main tree species), (II) insight into the spatial distribution of delineated strata inside the compartment, and (III) with respect to rules of the Regulation on forest management $[70,71]$.

\section{Method for photogrammetric measure- ment of stand structure elements}

Development of method for photogrammetric measurements of stand structure elements was carried out in the stereomodel of CIR digital aerial images in StereoDraw module. Additional data processing was performed in Global Mapper software and OpenOffice spreadsheet calculator. An overall procedure of photogrammetric measurement of stand structure elements at one circular sample plot is described in the following example (Figures 7 to 9). 


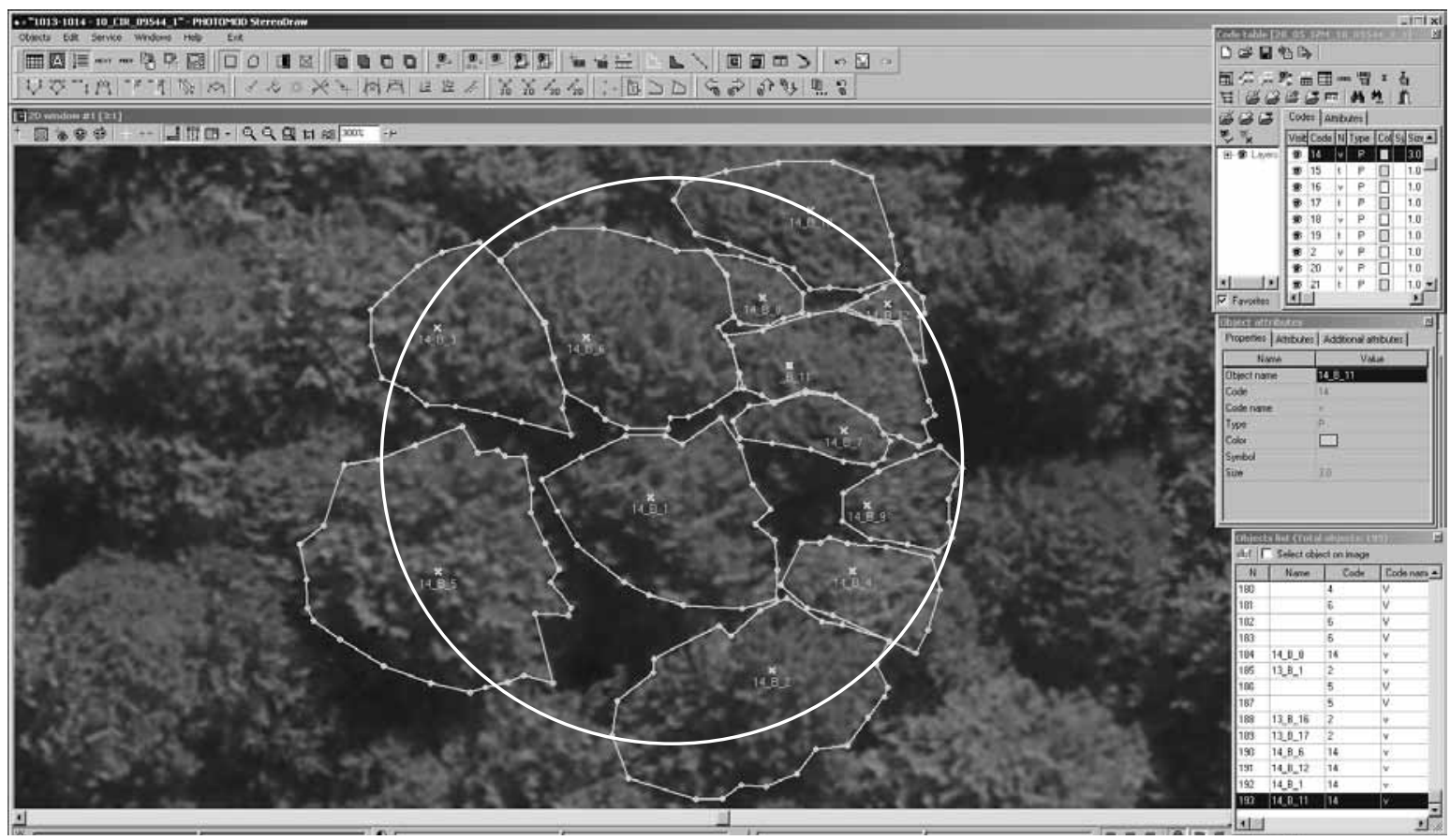

\section{FIGURE 7}

An example of a photogrammetric measurement of stand structure elements shown in model of CIR digital aerial images of GSD $10 \mathrm{~cm}$ in 2D window of StereoDraw module at magnification of $300 \%$.

Determination of tree species and crown top, as well as crown delineation were performed for each tree on the plot (Figure 7).

Tree species were recognized by a photogrammetry expert that had previously underwent training on plots with trees of known species. Species determination was performed on stereomodel of CIR digital aerial images by visual interpretation based on the general appearance of tree crowns (form, structure and crown texture) and crown colour.

The crown top of each tree, with its top falling inside circular plot, was determined and marked by placing stereo-marker on it and creating a 3D point object with $x, y, z$ coordinates (where $z$ is height in meters above sea level). Each point, representing single tree top, was labelled with a unique code (e.g. 14_B_1 - plot number, tree species (beech), tree number).

Finally, the crown area of each tree on the plot was manually delineated and represented by a polygon object. Data collected with StereoDraw module were recorded and stored in .DXF file format.

Data from .DXF files were then loaded as "trees" layer into Global Mapper software (Figure 8) using preloaded DEM as background layer and a reference for calculating tree height.

In order to calculate tree height $(h)$ and crown area $(C A)$ the following steps were performed:
- $\quad$ Selecting "trees" layer and choosing command "Export Vector Data $\rightarrow$ Export CSV" we exported elevation coordinate of tree tops $\left(h_{T}\right)$ into .CSV format (Figure 9) which we could process with spreadsheet calculator (OpenOffice).

- In order to obtained the elevation of the tree's "bottom" $\left(h_{B}\right.$; i.e. elevation of orthogonal projection of tree top point) from the associated tree top points and DEM we used "Apply Elevations from Terrain Layers to Selected Points" command, and then we exported data into CSV file.

- The height $(h)$ of each tree on the plot is calculated as $h=h_{T}-h_{B}$.

- Polygons representing tree crowns were selected and command "Display Feature Measurements" was used to show and subsequently export in CSV format the areas of each polygon representing orthogonal projection of tree crown area (CA).

In such a presented way, the obtained data are ready for further processing, i.e. for importing into the appropriate database and for calculation of necessary stand structure elements $(h, d b h, g, v, N, G, V)$.

The diameter at breast height $(d b h)$ of each tree in the plot could be calculated if appropriate regression models for $d b h$ estimation exist. In such cases, as independent variables the regression models usually use crown area $(C A)$ or crown diameter $(D)$ in case of univariate models, or any combination of $C A$, tree height $(h)$, number of trees per hectare $(N)$ in case of multivariate models. 


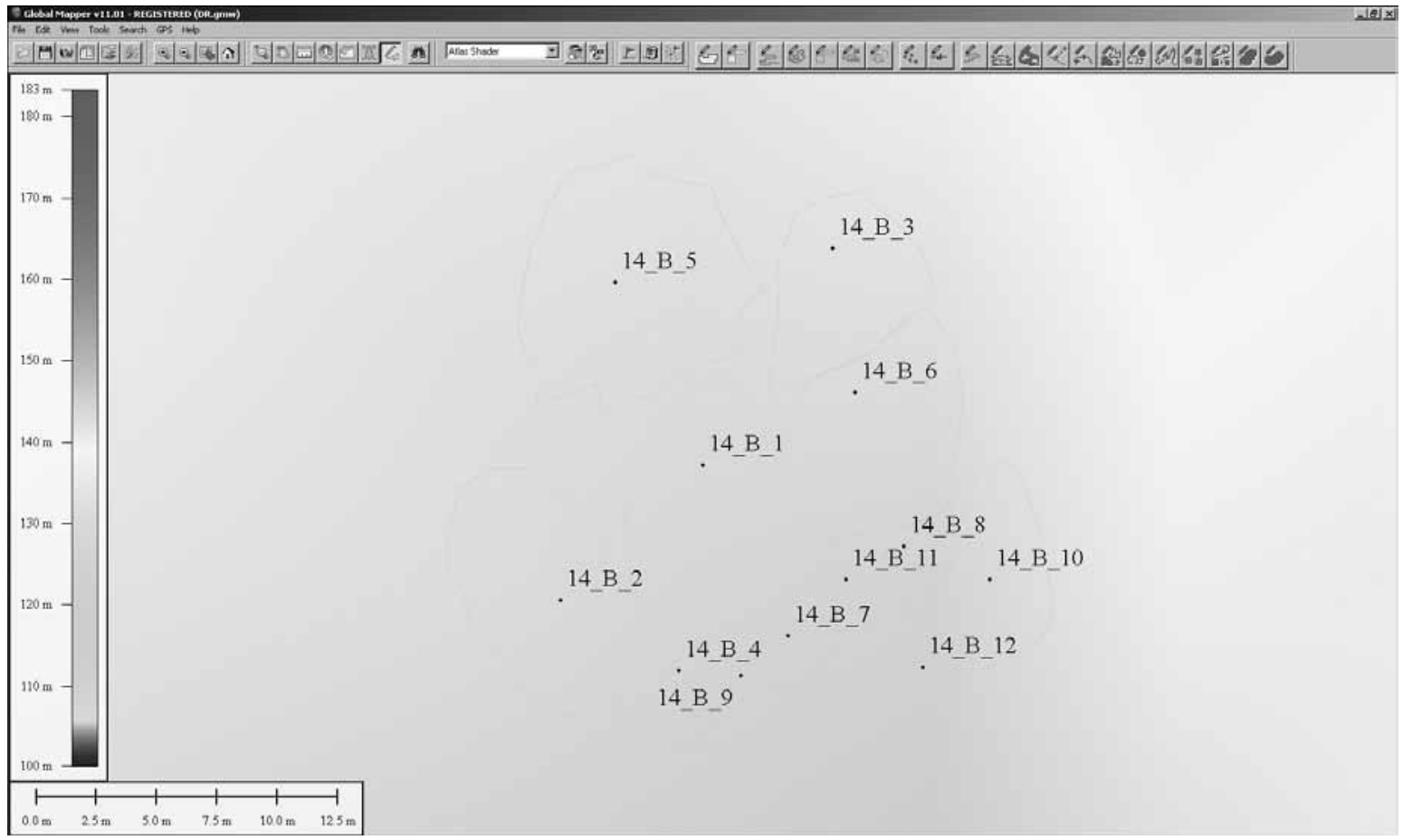

\section{FIGURE 8}

Objects collected in the StereoDraw module and loaded in the Global Mapper software for further processing

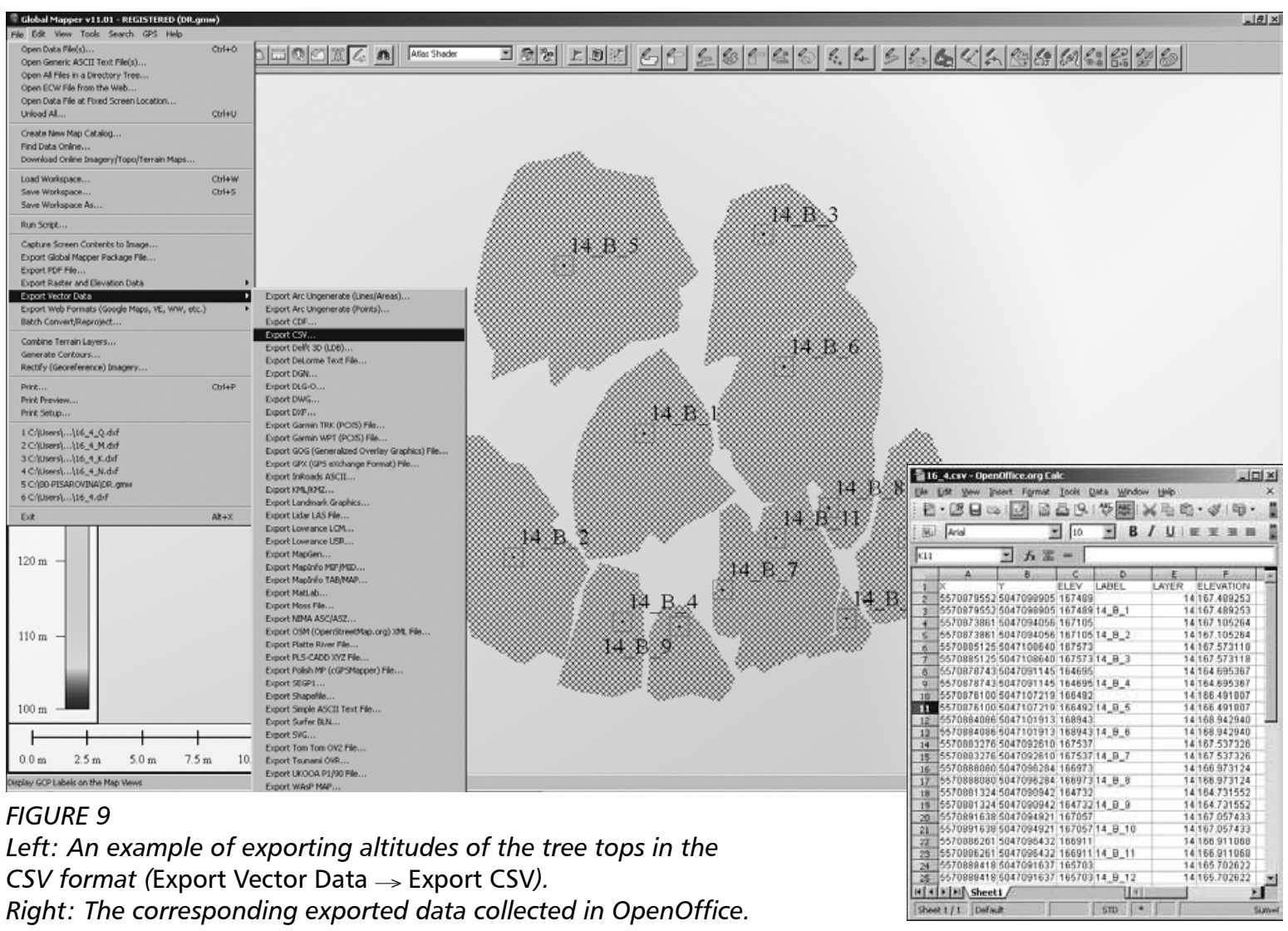




\section{DISCUSSION AND CONCLUSIONS}

Development of digital photogrammetry, application of which has been mentioned earlier, has made it one of the most important methods of collecting spatial data in many disciplines (geodesy, geography, geology etc.). Since the remote sensing methods have not yet reached wider practical application in Croatian forestry, focus of our work was development of methodology for potential application of digital photogrammetry in forest management, in particular on tasks of creating management division and measuring stand structure elements.

According to previous research [34], some of major limitations in application of digital photogrammetry in forestry, were non user-friendly software and insufficient hardware performances then existing DPWs. In addition, photogrammetric images were acquired in lower spatial resolution than today. However, at present, due to constant development of computer performances, as well as increased image availability a significant advancement in photogrammetric software has occurred.

The software presented and used in this paper (PHOTOMOD Lite and Global Mapper) in combination with the used DPW are designed in 'user friendly' manner so that relatively low level of photogrammetry and GIS expertise is needed in order to completely satisfy the needs for strata delineation and stand structure measurements. The PHOTOMOD software enables simple creation of projects of digital images, easy manipulation of multiple digital images, and many other features that facilitate photogrammetric measurement and photo-interpretation, but its free version PHOTOMOD Lite has limited capabilities in terms of number of images and quantity of vector data that can be processed. However, since our work was focused on the method and not for real forest management purpose, the capabilities of the used software were sufficient.

If digital images of high spatial resolution are used (e.g. $30 \mathrm{~cm}$ or better), as was the case in this research (GSD $10 \mathrm{~cm}$ ), stereo-effect experienced by the operator and the quality of photo-interpretation are very good. That enables clear determination of vegetation types and as well as single tree species, more accurate pinpointing of tree tops and more accurate delineation of tree crowns. Since all tasks of delineation and measurement are performed on computer, and data are already integrated into GIS environment, necessary are only minor corrections of delineated strata (e.g. according to cadastral data) followed by grouping of delineated strata into forest compartments and subcompartments. In contrast, with classical method, all data collected in the field have to be typed in computer, or at best downloaded from several field computers to the mainframe, checked and processed. Furthermore, field data on delineation of stands (e.g. notes from paper maps, or point from field computers) have to be translated in the GIS environment.

Recent research examine differences in work effort needed to perform typical tasks in forest management planning. Balenović [72] compared the worktime and costs for stand mapping and tree measurement in forest inventory with photogrammetric and classical forestry methods. From his results can be seen that photogrammetric method (conducted on digital images of GSD $30 \mathrm{~cm}$ ), requires $52,5 \%$ less work-time in total, namely $7 \%$ more for forestry engineer, but $67 \%$ less work-time for technicians and workers. It is also noteworthy that photogrammetry method required approx. $47 \%$ of work-time to be used in the field (manly forestry technician and worker) while classical method required almost $95 \%$ of time for field work. This is important information in terms of productivity which, primarily for classical method, decreases as weather conditions or terrain configuration deteriorates.

Another advantage of digital photogrammetry is that overall photogrammetric measurement and photo-interpretation in (permanently) recorded in digital form. This allows easy control at any point in time (unlike the control of the field measurement) and possibility for reprocessing the data in future (e.g. testing of some future automated method for tree species recognition, crown delineation etc.).

Nevertheless, photogrammetric method has some obstacles which have to be resolved before its full application in everyday forest management would be possible. Most common problems related with photogrammetric method are additional costs caused by acquiring DPWs, photogrammetric software and most important digital images. However, these are digital-technology related problems that are becoming less pronounced as technology advances and increases availability of DPWs and digital photogrammetric images. More important problem, that will require solving before photogrammetric method would become generally accepted, is development of procedures and software solutions capable of automatic, or at least semi-automatic, image processing for delineation of both forest strata and individual trees. It can be assumed that these challenges, related to pattern recognition, might be addressed in foreseeable future. However, other issues, like accurate tree species recognition, or tree measurements with automatic methods, will probably be more difficult to resolve.

As long as automatic procedures are not available, digital photogrammetry has to rely on manual methods. But even manual method could find its application in forest management planning as was shown earlier [72]. 
One of the most important tasks in current photogrammetric research is, aside from above mentioned issues, research of allometric relations and models that would link desired variables ( $\mathrm{dbh}$, tree basal area or tree volume) with variables measured in photogrammetry (tree crown diameter or area, tree height). Those relations vary with tree species, management history, site index, etc. If photogrammetric method is to be used as an alternative method, that provides equal or better results in comparison to the classical method, those models would have to be developed and tested. An attempt to address this issue, at least in part, is made within the ongoing project 'Application of digital photogrammetry in practical forest management'.

\section{ACKNOWLEDGMENTS:}

Research presented in this paper is carried out within the project "Growth and development of forest in different ecological conditions and under different management" financed by Ministry of Sciences, Education and Sport, and 'Application of digital photogrammetry in practical forest management', financed by Croatian Forests Ltd.

\section{REFERENCES}

1. DONASSY V, OLUIĆ M, TOMAŠEGOVIĆ Z 1983 Daljinska istraživanja u geoznanostima. JAZU, Zagreb, p 281-329

2. PERNAR R, ŠELENDIĆ D 2006 Prilog povećanju interpretabilnosti aerosnimaka i satelitskih snimaka za potrebe uređivanja šuma. Glas šum pokuse 5: 467-477

3. TOMAŠEGOVIĆ Z 1954 O pouzdanosti aerofototaksacije za neke dendrometrijske potrebe šumskog gospodarstva. Glas šum pokuse 12: 167-220

4. TOMAŠEGOVIĆ Z 1956 Razmatranja o fotoplanu Turopoljskog luga. Šum list 80 (5-6): 154-166

5. TOMAŠEGOVIĆ Z 1961a Sterefotogrametrijska linearna taksacija. Šum list 85 (1-2): 36-45

6. TOMAŚEGOVIĆ $Z$ 1961b Ovisnost promjera d1,3 jele $\mathrm{i}$ smreke o krošnji i visini stabala. Šum list 85 (7-8): 254261

7. TOMAŠEGOVIĆ Z 1965 O pouzdanosti fotogrametrijskih slojnica šumskih područja. Geod list 19 (10-12): 259-304

8. VUKELIĆ J 1984 Doprinos fotointerpretacijske analize vegetaciji istraživanih šumskih zajednica Nacionalnog parka Risnjak. Master's thesis, Faculty of Forestry, University of Zagreb, p 81

9. ĆURIĆ T 1986 Fotointerpretacijsko izlučivanje sastojina. Bachelor's thesis, Faculty of Forestry, University of Zagreb, p 22

10. BENKO M 1993 Procjena taksacijskih elemenata sastojina na infracrvenim kolornim aerosnimkama. Glas šum pokuse 29: 199-274

11. PERNAR R 1997 Application of results of aerial photograph interpretation and geographical information system for planning in forestry. Glas šum pokuse 34 : 141-149

12. KLOBUČAR D 2004 Izlučivanje sastojina prema sklopu na digitalnom ortofotu i usporedba $s$ terestičkim izlučivanjem. Rad Šumar Inst (39) 2: 223-230

13. SELETKOVIĆ A, PERNAR R, BENKO M, 2006 Višefazni uzorak u inventarizaciji šumskog prostora. Rad Šumar Inst 9: 297-306

14. LUKIĆ N 1981 Ispitivanje pouzdanosti fotointerpretacijske inventure drvnih masa šuma jele u odnosu na listu podataka dobivenu mjernom fotointerpretacijom. Šum list 105 (3-4): 133-145

15. KUŠAN V 1992 Procjena volumena sastojina četinjača fotointerpretacijom aerosnimaka uz pomoć prirasnoprihodnih tablica. Meh šumar 17 (3-4): 53-66

16. KUŠAN V, KREJČI V 1993 Regresijski model za procjenu volumena sastojina hrasta lužnjaka. Rad Šumar Inst 28 (1-2): 69-77
17. BENKO M 1995 Procjena drvne zalihe sastojine multivarijantnom analizom čimbenika mjerljivih na aerosnimkama. Dissertation, Faculty of Forestry, University of Zagreb, p 237

18. PAVICIĆ D 1983 Pouzdanost fotointerpretacijskog određivanja horizontalnog sklopa u sastojinama. Bachelor's thesis, Faculty of Forestry, University of Zagreb, p 54

19. KOSTIJAL V 1986 Korelacijski odnos uočljivog broja krošnji u stereomodelima jednodobnih šuma bukve s prsnim promjerom centralnog plošnog stabla. Master's thesis, Faculty of Forestry, University of Zagreb, p 56

20. PERNAR R, KLOBUČAR D, KUŠAN V 2003 The application of aerial photographs from cyclic recordings in the Republic of Croatia to forest management. Glas šum pokuse 40: 113-168

21. PERNAR R, KLOBUČAR D 2003 Estimating stand density and condition with use of picture histograms and visual interpretation of digital orthophotos. Glas šum pokuse 40: 81-111

22. KLOBUČAR D 2008 Primjena histograma drugoga reda u procjeni relativnog sastojinskog obrasta. Šum list 132 (9-10): 419-429

23. KLOBUČAR D, PERNAR R 2009 Umjetne neuronske mreže u procjeni sastojinskih obrasta s cikličkih snima$\mathrm{ka}$. Šum list 133 (3-4): 145-155

24. KALAFADŽIĆ Z, KUŠAN V 1990 Ustanovljavanje stanja šuma na velikim površinama, primjenom infracrvenih kolornih aerosnimaka. Glas šum pokuse 26: 447-459

25. PERNAR R 1994 Način i pouzdanost određivanja oštećenosti hrasta lužnjaka (Quercus robur L.) na infracrvenim kolornim (ICK) aerosnimkama. Glas šum pokuse 31: 1-34

26. PERNAR R, SELETKOVIĆ A, ANČIĆ M 2007a Utvrđivanje oštećenosti šuma Spačvanskog bazena primjenom infracrvenih kolornih aerosnimaka. Šum list 131 (7-8): 315-322

27. PERNAR R, ANČIĆ M, SELETKOVIĆ A 2007b Primjena ICK aerosnimaka za utvrđivanje oštećenosti šuma na području UŠP Gospić. Šum list 131 (11-12): 507-521

28. PERNAR R, SELETKOVIĆ $A$, ANČIĆ $M$, VEDRIŠ M, TESLAK $K 2008$ Assessing the health status of beech-fir forests using remote sensing methods. Period Biol 110 (2): 157-161

29. PERNAR R, SELETKOVIĆ $A$, ANČIĆ $M$, SUČIĆ J 2011: Značajke prostorne distribucije sušaca u bukovo-jelovoj šumi (Features of Spatial Snag Distribution in a BeechFir Forest). Croat J For Eng 32 (1): 313-327 
30. KLOBUČAR D, PERNAR R, LONČARIĆ $S$, SUBAŠIĆ $M$, SELETKOVIĆ A, ANČIĆ M 2010 Detecting forest damage in CIR aerial photographs using a neural network. Croat J For Eng 31 (2): 157-163

31. KUŠAN V 1996 Pristup daljinskim istraživanjima i GIS-u u Hrvatskome šumarstvu. Šum list 120 (3-4): 171-178

32. BALENOVIĆ I, MARJANOVIĆ H, BENKO M 2010 Primjena aerosnimaka u uređivanju šuma u Hrvatskoj. Šum list 134 (11-12): 623-631

33. LAPAINE M, FRANČULA N 2001 O pojmovima analogno i digitalno. Bilt dalj istr fotoint 15-16: 135-144

34. MAGNUSSON M, FRANSSON J E S, OLSSON H 2007 Aerial photo-interpretation using Z/I DMC images for estimation of forest variables. Scand J Forest Res, 22 (3): 254-266

35. LINDER W 2009 Digital photoogrammetry - A practical course. Springer, Berlin, p 220

36. SCHENK T 2005 Introduction to photogrammetry. Department of Civil and Environmental Engineering and Geodetic Science, The Ohio State Universitiy, Columbus, p 95. Available at: http://gscphoto.ceegs.ohiostate.edu/courses/GeodSci410/docs/GS410 02.pdf (Accessed: 12 October 2009)

37. CRAMER M 2005 Digital airborne cameras - status and future. In: Heipke C, Jacobsen K, Gerke M (eds) High resolution earth imaging for geospatial information. ISPRS, Hanover, p 1-8

38. CICELI T, GAJSKI D 2007 Digital large format airborne cameras. KiG (Kartografija i geoinformacije) 6 (7): 4051

39. SANDAU R 2010 Digital airborne camera, introduction and technology. Springer, Dordrecht, p 343

40. HINZ A, HEIER H 2000 The Z/l imaging digital camera system. Photogramm Rec 16 (96): 929-936

41. CICELI T 2004 Primjena digitalne kamere u terestričkoj fotogrametriji. Master's thesis, Faculty of Geodesy, University of Zagreb, p 92

42. TONKOVIĆ T 2006 Vexcel-Ultracam. KiG 5 (5): 116-119

43. PETRIE G, WALKER A S 2007 Airborne digital imaging technology: a new overview. Photogramm Rec 22 (119): 203-225

44. GRUBER M, WIECHERT A 2009 UltracamXp, The new Vexcel Imaging/Microsoft. In: Proceedings of the American Society for Photogrammetry and Remote Sensing. March 2009, Baltimore, Maryland

45. JACOBSEN K 2009 Potential of large format digital aerial cameras. Map World Forum Hyderabad, GIS Development. Available at: http://www.ipi.uni-hannover.de/ uploads/tx_tkpublikationen/DigitalCameras_Jacobsen. pdf (Accessed: 15 September 2010)

46. PETRIE G 1997 Developments in digital photogrammetric systems for topographic mapping applications. ITC Journal 2: 121-135

47. AHMAD A 2008 Digital photogrammetry: an experience of processing aerial photograph of utm acquired using digital camera. Available at: http://eprints.utm. my/490/1/Anuar_Ahmad_fksg.pdf (Accessed: 15 April 2010)

48. MADANI M 1996 Digital aerial triangulation - the operational comparison. In: International Archives of Photogrammetry and Remote Sensing, Vienna, 31 (part B3), 490-495

49. WALKER A S, PETRIE G 1996 Digital photogrammetric workstations 1992-1996. In: International Archives of Photogrammetry and Remote Sensing, Vienna, 31 (part B2): 384-395
50. RUZGIENÉ B 2007 Comparison between digital photogrammetric systems. Geodezija ir Kartografija (Geodesy and Cartography) 33 (3): 75-79

51. HEIPKE C 2001 Digital photogrammetric workstations - a review of the state-of-the-art for topographic applications. GIM International 15 (4): 35-37

52. LEMMENS M 2007 Product survey on DPW. GIM International 21 (12): 22-25

53. LEMMENS M 2009 Product survey. Digital photogrammetric workstations. Available at: http://www.giminternational.com/productsurvey/id36-Digital_Photogrammetric_Workstations,_December.html (Accessed: 20 January 2010 )

54. BENKO M, BALENOVIĆ I 2011 Prošlost, sadašnjost i budućnost primjene metoda daljinskih istraživanja pri inventuri šuma u Hrvatskoj. Šum list 135 (13): 272-281

55. ANTTILA P 2002 Nonparametric estimation of stand volume using spectral and spatial features of aerial photographs and old inventory data. Can J Forest Res 32 (10): 1849-1857

56. N/ESSET E 2002 Determination of mean tree height of forest stands by means of digital photogrammetry. Scand J Forest Res 17 (5): 446-459

57. POULIOT D A, KING D J, BELL F W, PITT D G 2002 Automated tree crown detection and delineation in highresolution digital camera imagery of coniferous forest regeneration. Remote Sens Environ 82 (2-3): 322-334

58. LECKIE D G, GOUGEON F A, WALSWORTH N, PARADINE D 2003 Stand delineation and composition estimation using semi-automated individual tree crown analysis. Remote Sens Environ 85 (3): 355-369

59. LECKIE D G, GOUGEON F A, TINIS S, NELSON T, BURNET C N, PARADINE D 2005 Automated tree recognition in old growth conifer stands with high resolution digital imagery. Remote Sens Environ 94 (3): 311-326

60. KORPELA I 2004 Individual tree measurements by means of digital aerial photogrammetry. Silva Fenn Monogr 3: 1-93

61. KORPELA I, ANTTILA P 2004 Appraisal of the mean height of trees by means of image matching of digitised aerial photographs. Photogrammetric Journal of Finland 19 (1): 23-36

62. ZAGALIKIS G, CAMERON A D, MILLER D R 2005 The application of digital photogrammetry and image analysis techniques to derive tree and stand characteristics. Can J Forest Res 35 (5): 1224-1237

63. KE Y QUACKENBUSH L J 2009 Individual tree crown detection and delineation from high spatial resolution imagery using active contour and hill-climbing methods. In: Proceedings of 2009 ASPRS Annual Conference, 9-13 March 2009, Baltimore, Maryland

64. KING D J 2000 Airborne remote sensing in forestry: sensors, analysis and applications. Forest Chron 76 (6): $25-42$

65. DGU 2004 301D150 Product Specification Digital Terrain Model CRONO GIP. The State Geodetic Administration, Zagreb, p 117

66. RACURS 2010a PHOTOMOD Lite. Available at: http:// www.racurs.ru/?page $=705$ (Accessed: 20 October 2010)

67. GLOBAL MAPPER SOFTWARES 2010. Available at: http:// www.globalmapper.com/ (Accessed: 21 October 2010)

68. RACURS 2009 PHOTOMOD 4.4. Module Montage Desktop, User Manual. Racurs, Moscow. Available at: http:// www2.racurs.ru/docs/en/md.pdf (Accessed: 25 October 2010) 
69. RACURS 2010b PHOTOMOD StereoDraw. Available at: http://www.racurs.ru/?page=555\#SD (Accessed: 20 October 2010)

70. THE MINISTRY OF AGRICULTURE, FORESTRY AND WATER MANAGEMENT 2006 Regulation on forest management. Official Gazette, Zagreb, 111
71. THE MINISTRY OF REGIONAL DEVELOPMENT, FORESTRY AND WATER MANAGEMENT 2008 Regulation on forest management. Official Gazette, Zagreb, 141

72. BALENOVIĆ I 2011 Applying possibility of digital Aerophotogrammetric images of different spatial resolution in forest management. Dissertation, Faculty of Forestry, University of Zagreb, p 186 